\title{
DISKURSUS KONSEP DAN PRINSIP AKAD DALAM HUKUM ISLAM
}

\section{Oleh: Hendra Cipta ${ }^{1}$}

\begin{abstract}
Contract has an important role in the agreement and the engagement of either Islamic law or in the positive law. The existence of the contract with the Islamic principles would sustain the contract to the benefit and avoid deception and frand between the parties. Islamic principles are based on permissible, voluntary, welfare and justice needs to be embedded in the Islamic contracts. If these principles are at parties, then the contract will not be a contract that is imperfect.
\end{abstract}

Keywords: Contract Concept, Contract Principle, Islamic Law

\section{A. Pendahuluan}

Hubungan dan pergaulan manusia dengan manusia lain akan menimbulkan berbagai macam ikatan dalam masyarakat. Setiap ikatan dilakukan oleh masingmasing anggota masyarakat untuk mempertahankan nilai-nilai kemanusiaan selaku makhluk Allah, yaitu dengan memelihara ikatan batin antara individu dalam bermasyarakat, di samping juga perjuangan individu untuk memenuhi kebutuhan hidupnya yang bersifat materil. Masing-masing mengadakan perikatan yang berupa perjanjian (akad), seperti akad jual-beli, sewa-menyewa, hutang piutang, dan lain-lain. Tujuan pokok akad adalah untuk mengatur hubungan yang saling menguntungkan dan kemashlahatan serta kemanfaatan, tolong-menolong antara pihak-pihak yang melakukan kerasama agar semuanya berjalan baik dan lancar. ${ }^{2}$

Akad merupakan kesepakatan dalam suatu perjanjian antara dua pihak atau lebih untuk melakukan ataupun tidak melakukan perbuatan hukum tertentu. ${ }^{3}$ Akad merupakan tindakan hukum dua pihak karena akad adalah pertemuan ijab yang mempresentasikan keinginan salah satu pihak yang melakukan akad dan qabul

${ }^{1}$ Dosen Jurusan Syariah dan dan Ekonomi Islam STAIN Syaikh Abdurahman Siddik Bangka Belitung, email: hendracipta80@yahoo.com

2 Zahri Hamid, Asas-asas Mu'amalah Tentang Fungsi Akad Dalam Masyarakat (Yogyakarta: IAIN Sunan Kalijaga, t.t.), hlm, 24.

3 Pusat Pengkajian Hukum Islam dan Masyarakat Madani (PPHIMM), Kompilasi Hukum Ekonomi Syari'ah, edisi revisi (Jakarta: Kencana, 2009), hlm. 15. 


\section{Diskursus Konsep dan Prinsip Akad dalam Hukum Islam}

merupakan keinginan pihak lain yang juga terlibat pada akad. ${ }^{4}$ Pada sisi lain, akad juga diartikan sebagai pertalian ijab (pernyataan melakukan ikatan) dan kabul (pernyataan penerimaan ikatan) sesuai dengan kehendak syariat yang berpengaruh pada objek perikatan.

Makna "sesuai dengan kehendak syari'at" yaitu seluruh perikatan yang dilakukan oleh dua pihak atau lebih tidak boleh apabila tidak sejalan dengan kehendak syara', misalnya kesepakatan antara beberapa orang atau badan bertransaksi dengen riba, menipu orang lain, atau merampok kekayaan orang lain. Adapun pencantuman kalimat "berpengaruh pada objek perikatan" maksudnya adalah berpindahnya kepemilikan objek akad yang ditransaksikan dari pihak penjual kepada pihak pembeli atau dari pihak yang menyampaikan ijab kepada pihak yang menjawab ijab dengan kabul.

Mustafa Anas az-Zarqa (tokoh fikih Yordania asal Suriah) menyatakan bahwa tindakan hukum yang dilakukan manusia terdiri dari dua bentuk, yaitu (1) tindakan dalam bentuk perbuatan dan (2) tindakan dalam bentuk perkataan. Tindakan dalam bentuk perkataan ada dua macam, yaitu yang bersifat akad dan yang tidak bersifat akad. Tindakan berupa perkataan yang bersifat akad terjadi bila dua atau lebih dari pihak-pihak yang melakukan akad sama-sama mengikatkan diri dengan perikatan dalam suatu perjanjian. Berdasarkan pembagian tindakan hukum ini, lanjut Mustafa Ahmad az-Zarqa, suatu tindakan hukum lebih umum dari akad. Setiap akad dikatakan sebagai tindakan hukum dari dua atau beberapa pihak, tetapi sebaliknya setiap tindakan hukum tidak dapat disebut sebagai akad. ${ }^{5}$

Dalam dunia usaha, perjanjian usaha menduduki posisi yang amat penting. Karena perjanjian itulah yang membatasi hubungan antara dua pihak yang terlibat dalam pengelolaan usaha, dan dengan adanya perjanjian ini akan mengikat pihakpihak yang menandatangani akad sampai dengan berakhirnya akad tersebut. Karena dasar dari adanya hubungan itu adalah pelaksanaan apa yang menjadi orientasi kedua orang yang melakukan perjanjian, dijelaskan dalam perjanjian oleh keduanya.

${ }^{4}$ Syamsul Anwar, Hukum Perjanjian Syari'ah: Studi tentang Teori Akad dalam Fikih Muamalat, cet. ke-2 (Jakarta: Rajawali Press, 2010), hlm. 69.

5 Abdul Aziz Dahlan (ed.) et.al., Ensiklopedi Hukum Islam, cet.1, (Jakarta: Ichtiar Baru van Hoeve, 1996),I: 63. 


\section{Diskursus Konsep dan Prinsip Akad dalam Hukum Islam}

Warisan ilmu fiqh (mu'amalat) memuat berbagai rincian dan penetapan dasardasar perjanjian-perjanjian usaha, sehingga dapat merealisasikan tujuannya, memenuhi kebutuhan umat di dunia modern saat ini, kaidah-kaidah yang ada pada fiqh muamalat ini bisa diaplikasikan pada bisnis modern. Semakin jelas dan semakin detail rincian serta kecermatan dalam membuat perjanjian usaha, semakin menutup peluang munculnya potensi konflik dan pertentangan antara pihak-pihak yang berakad. $^{6}$

Untuk menemukan benang merah dari konsep akad dalam hukum perjanjian Islam dan aplikasinya di lembaga keuangan syari'ah khususnya bank syari'ah, maka pemakalah mencoba menulis makalah ini untuk meneropong antara teori dan aplikasi akad.

\section{B. Pengertian Akad (perjanjian).}

Kata akad berasal dari bahasa Arab, yang lazimnya di sebut 'aqada dari kata 'aqada, ya'qidu, 'aqdan, yang berarti mengikat, mengumpulkan dan janji.' Akad yang asal katanya mengikat dan mengumpulkan tersebut bermakna menghubungkan dua ujung tali dan saling mengikatkan dua ujung tali tersebut sehingga satu sama lainnya saling bersambung, kemudian keduanya bersambung menjadi sepotong benda. ${ }^{8}$

Istilah perjanjian dalam al-Qur'an di kenal dengan istilah 'abdun (Q.S. Ali Imran (3): 76) dan 'aqdun (Q.S. Al-Maidah (5): 1). 'Ahdun adalah suatu pernyataan dari seseorang untuk mengerjakan sesuatu tanpa ada sangkut-pautnya dengan kemauan orang lain, sedangkan 'aqdun terjadi pada dua pihak yang melakukan pekerjaan yang saling mengikatkan diri. Antara kedua belah pihak sepakat untuk saling melakukan hak dan kewajibannya masing-masing. Dalam rangka menghilangkan perselisihan dan untuk menjaga serta melindungi hak-hak dan kewajibannya masing-masing, perjanjian hendaknya dilakukan secara tertulis (Q.S. Al-Baqarah (2): 282).

${ }^{6}$ Abdullah al-Mushlih dan Shalah ash-Shawi, Fikih Ekonomi Kenangan Islam, diterjemahkan oleh Abu Umar Basyir (Jakarta: Darul Haq, 2004), hlm. 25.

7 Ahmad Warson Munawwir, Al-Munawwir Kamus Arab Indonesia, (Yogyakarta: PP alMunawwir Krapyak, 1984), hlm. 1023. Dikutip juga dari Ali bin Muhammad al-Jumu'ah, Mu'jam alMusthalahat al-Iqtishadiyah wa al-Islamiyah (Riyad: Maktabah al-'Abikan, $1421 \mathrm{H} / 2000 \mathrm{M}$ ), hlm. 383.

${ }^{8}$ S. E. Rayner, The Theory of Contract in Islamic Law (London: Bordrecht/Boston: Graham and Trorman, 1991), hlm. 5. 


\section{Diskursus Konsep dan Prinsip Akad dalam Hukum Islam}

Akad atau perjanjian adalah suatu ikatan antara dua pihak atau lebih tentang sesuatu urusan tertentu yang dimulai dengan kehendak salah satu pihak kemudian disetujui oleh pihak lain sehingga merupakan kesepakatan semua pihak yang bersangkutan. ${ }^{9}$

Apa yang dinamakan perjanjian adalah hubungan hukum antara dua pihak atau lebih berdasarkan kata sepakat untuk menimbulkan akibat hukum. Dua pihak itu sepakat untuk menentukan peraturan, kaedah, hak, dan kewajiban yang mengikat mereka untuk ditaati dan dijalankan. Kesepakatan itu adalah untuk menimbulkan akibat hukum, menimbulkan hak dan kewajiban. Jika kesepakatan itu di langgar maka ada akibat hukumnya; si pelanggar dapat dikenakan akibat hukum (sanksi). ${ }^{10}$

Adapun menurut istilah syara', As-Sanhury dalam kitabnya Nazariyyah al-'Aqd Syarh al-Qanun mengutip dari kitab Mursyid al-Hairan mengemukakan bahwa yang di maksud dengan akad (perjanjian) adalah suatu perbuatan hukum dimana seorang atau lebih mengikatkan dirinya terhadap orang lain. ${ }^{11}$ Menurut Ahmad Azhar Basyir akad adalah suatu perikatan ijab kabul dengan cara yang telah dibenarkan oleh syara' dan menetapkan adanya akibat hukum pada obyeknya. ${ }^{12}$

Menurut istilah fuqaha akad adalah perikatan antara ijab dengan qabul secara yang dibenarkan syara', yang menetapkan persetujuan kedua belah pihak. ${ }^{13}$ Gambaran yang menerangkan maksud diantara dua belah pihak itu dinamakan $i j a b^{14}$ dan qabul..$^{15}$ Akad adalah suatu macam tasharruf ${ }^{16}$ yang dilakukan manusia. Tasharruf menurut fiqh

\footnotetext{
${ }^{9}$ Ibid., hlm. 13.

${ }^{10}$ Sudikno Mertokusumo, Mengenal Hukum Suatu Pengantar (Yogyakarta: Liberty, 1986), hlm. 97.

11 Abd. Ar-Razzaq as-Sanhury, Nadzariyahal-'Aqd (Beirut: Dar al-Fikr, t.t.), hlm. 80. Dikutip juga dari Mhd. Syahnan, Modernization of Islamic Law of Contract (Jakarta: Badan Litbang dan Diklat Departemen Agama RI, 2009), hlm. 124.

12 Ahmad Azhar Basyir, Asas-asas Hukum Mu'amalat (Hukum Perdata Islam) (Yogyakarta: Perpustakaan Fakultas Hukum UII, 1993), hlm. 42.

${ }_{13}$ Ghufron A. Mas'adi, Fiqh Muamalab Kontekstual, cet. 1 Jakarta: Raja Grafindo Persada, 2002), hlm. 76. Faturrahman Djamil, "Hukum Perjanjian Syari'ah", dalam Kompilasi Hukum Perikatan oleh Mariam Darus Badrulzaman, et.al, cet.1 (Bandung: Citra Aditya Bakti, 2001), hlm. 247.

14 Ijab ialah permulaan penjelasan yang keluar dari salah seorang yang berakad, untuk memperlihatkan kehendaknya dalam mengadakan akad, siapa saja yang memulainya. Dikutip dari Muhammad Hasbi ash-Shiddieqy, Pengantar Figh Muamalah, (Semarang: Pustaka Rizki Putra, 1999), hlm. 27. Ibid, hlm. 27.

${ }^{15}$ Qabul ialah jawaban pihak yang lain sesudah adanya ijab, untuk menyatakan persetujuannya.

16 Secara terminologis tasharruf berarti segala ucapan atau tindakan yang muncul dari seseorang berdasarkan kehendaknya, dan syara' telah memberikan akibat hukum terhadapnya, baik
} 


\section{Diskursus Konsep dan Prinsip Akad dalam Hukum Islam}

adalah segala yang dilakukan dari seseorang dengan iradat nya (kehendaknya), dan syara' menetapkan kepada orang tersebut beberapa hak. ${ }^{17}$

Menurut Husein Hamid Hasan sebagaimana di kutip oleh Niazi mendefinisikan akad adalah penghubung dua hal yaitu penawaran (ijab) dan penerimaan (qabul). Sedangkan Edward William Lane menyatakan bahwa akad adalah kontrak, kesepakatan, perjanjian, persetujuan, ikatan, fakta, dan pertunangan. ${ }^{18}$ Sedangkan menurut Mursyid al-Huraian akad berarti penawaran yang berasal dari satu diantara dua orang atau kelompok yang melakukan kontrak; dimana pihak kedua setuju dengan materi kontrak yang diajukan oleh pihak pertama. ${ }^{19}$

Kompilasi Hukum Ekonomi Syari’ah dalam buku II, bab I (ketentuan umum) pasal 20 mendefinisikan akad adalah kesepakatan dalam suatu perjanjian antara dua pihak atau lebih untuk melakukan dan/atau tidak melakukan perbuatan hukum tertentu. $^{20}$

Istilah perjanjian (overeenkomst) dalam hukum perdata ${ }^{21}$ diterjemahkan secara berbeda-beda oleh para sarjana hukum perdata, yaitu antara lain: Kitab UndangUndang Hukum Perdata, menggunakan istilah perjanjian untuk overeenkomst. ${ }^{22}$ Prof. Utrecht memakai istilah overeenkomst juga untuk istilah perjanjian. ${ }^{23}$ Prof Subekti

untuk kepentingan sendiri maupun untuk kepentingan orang lain. Dengan demikian tasharruf mencakup ucapan-ucapan yang keluar dari diri seseorang seperti jual beli, hibah, wakaf, iqrar dan perbuatan-perbuatan seperti mengambil hal-hal yang mubah, mengkonsumsi dan mengambil manfaatnya. Di kutip dari Wahbah az-Zuhaily, Al-Fiqh al-Islami wa Adillatubu, cet. III (Damsyiq: Dar al-Fikr, 1996), IV: 83.

${ }^{17}$ Ibid., hlm. 24-26..

${ }^{18}$ Liaquat Ali Khan Niazi, Islamic Law of Contract (Lahore: Research Cell, t.t.), hlm. 9.

${ }^{19}$ Ibid., hlm. 10.

${ }^{20}$ Mahkamah Agung Republik Indonesia, Kompilasi Hukum Ekonomi Syari'ah (t.tp: t.tn, 2008), hlm. 10. Dikutip juga dari Pusat Pengkajian Hukum Islam dan Masyarakat Madani (PPHIMM), Kompilasi Hukum ...., hlm. 15.

21 Menurut Sudikno Mertokusumo hukum perdata adalah hukum antar perorangan yang mengatur hak dan kewajiban perorangan yang satu terhadap yang lain di dalam hubungan keluarga dan di dalam pergaulan amsyarakat. Sedangkan menurut Wirjono Prodjodikoro hukum perdata adalah suatu rangkaian hukum antara orang dan badan hukum satu sama lain tentang hak dan kewajiban. Menurut H. F. A. Vollmar hukum perdata di sebut juga dengan hukum sipil atau hukum privat. Kutipan dari Sudikno Mertokusumo, Mengenal Hukum Suatu Pengantar, hlm. 108. R. Wirjono Prodjodikoro, Asas-Asas Hukum Perdata, cet. 11 (Jakarta: Sumur Bandung, 1992), hlm. 10-11. Lihat juga H. F. A. Vollmar, Pengantar Studi Hukum Perdata, diterjemahkan oleh I.S. Adiwinarta, cet. III (Jakarta: Rajawali Pers, 1992), hlm. 2.

22 R. Subekti dan R. Tjitrosudibio, Kitab Undang-Undang Hukum Perdata, cet.XXVIII, Jakarta: Pradnya Paramita, 1996), hlm. 338.

${ }^{23}$ Utrecht, Pengantar Dalam Hukum Indonesia, cet. V(Jakarta: Balai Buku Ikhtiar, 1959), hlm. 621. 


\section{Diskursus Konsep dan Prinsip Akad dalam Hukum Islam}

memakai istilah overeenkomst untuk perjanjian, bukan untuk persetujuan. ${ }^{24}$ Prof. R. Wirjono Prodjodikoro memakai istilah persetujuan untuk terjemahan overeenkomst. ${ }^{25}$

Pengertian perjanjian dalam hukum perdata juga beraneka ragam. Menurut Prof. Subekti, S. H perjanjian adalah suatu peristiwa dimana seorang berjanji kepada seorang lain atau dimana dua orang itu saling berjanji untuk melaksanakan sesuatu hal. ${ }^{26}$

R. Wirjono Prodjodikoro mendefinisikan perjanjian dengan interaksi hukum dalam bidang harta benda diantara dua pihak atau lebih yang melakukan perjanjian, dimana suatu pihak berjanji atau dianggap berjanji untuk melakukan sesuatu hal atau untuk tidak melakukan sesuatu hal dan pihak lain bisa mengajukan keberatan ataupun memperkarakan jika yang diminta melakukan prestasi tidak menunaikaan kewajibannya. ${ }^{27}$

Menurut R. Setiawan persetujuan (perjanjian) adalah suatu perbuatan hukum, ${ }^{28}$ dimana satu orang atau lebih mengikatkan dirinya atau saling mengikatkan dirinya terhadap satu orang atau lebih. ${ }^{29}$ Sedangkan menurut pasal 1313 KUH Per, perjanjian adalah suatu perbuatan dengan mana satu orang atau lebih mengikatkan dirinya terhadap satu orang lain atau lebih. ${ }^{30}$

Dalam hukum modern, kata kontrak biasanya ditujukan untuk perjanjian yang melibatkan pihak-pihak yang mempunyai konsekuensi legal (hukum) dan dapat dilakukan tindakan hukum terhadap pihak yang melakukan kecurangan. ${ }^{31}$

Kontrak akan menjadi aturan undang-undang khusus yang sangat mengikat ketika hal ini berhubungan dengan ekonomi, terutama dalam hal hutang-piutang.

\footnotetext{
${ }^{24}$ Subekti, Hukum Perjanjian, cet. XV (Jakarta: Intermasa, 1994), hlm. 1.

${ }^{25}$ R. Wirjono Prodjodikoro, Asas-Asas Hukum Perjanjian, cet. XI (Jakarta: Sumur Bandung, 1989), hlm. 8.

${ }^{26}$ Subekti, Hukum Perjanjian, hlm. 1.

${ }^{27}$ R. Wirjono Prodjodikoro, Asas-Asas Hukum Perjanjian, hlm. 9. Pengertian senada juga dikemukakan oleh Titodoningrat; menurutnya perjanjian adalah suatu perbuatan hukum berdasarkan kata sepakat diantara dua orang atau lebih untuk menimbulkan akibat-akibat hukum yang diperkenankan oleh undang-undang, di kutip dari K.R.M.T. Titodiningrat, Ikhtisar Hukum Perdata dan Hukum Dagang (Jakarta: Yayasan Pembangunan, 1952), hlm. 59.

${ }^{28}$ Perbuatan hukum adalah segala perbuatan yang dilakukan oleh manusia secara sengaja untuk menimbulkan hak dan kewajiban. Dikutip dari C.S.T. Kansil, Pengantar Ilmu Hukum dan Tata Hukum Indonesia (Jakarta: Balai Pustaka, 1986), hlm. 199.

${ }^{29}$ R. Setiawan Pokok-Pokok Hukum Perikatan, cet. IV (Bandung: Binacipta, 1990), hlm. 49.

${ }^{30}$ R. Subekti dan R. Tjitrosudibio, Kitab Undang-Undang Hukum Perdata, hlm. 338.

${ }^{31}$ Liaquat Ali Khan Niazi, Islamic Law.., hlm. 12-13.
} 


\section{Diskursus Konsep dan Prinsip Akad dalam Hukum Islam}

Aspek yang paling penting dalam perjanjian antara kedua belah pihak adalah adanya kepercayaan antara kedua belah pihak itu sendiri. ${ }^{32}$

Menurut Prof. Subekti perkataan perikatan (verbintenis) mempunyai arti yang lebih luas dari perkataan perjanjian. ${ }^{33}$ Perikatan lebih luas dari perjanjian, karena perikatan itu dapat terjadi karena perjanjian dan undang-undang.

Dengan demikian dapat disimpulkan, bahwa antara perjanjian (overeenkomst) dan perikatan (verbintenis) mempunyai hubungan, dimana perjanjian menerbitkan perikatan. Jadi, perjanjian melahirkan perikatan, dan perjanjian merupakan sumber terpenting yang melahirkan perikatan. ${ }^{34}$

Pada masa Rasulullah hidup beliau pernah melakukan beberapa praktek perjanjian diantaranya:

1. Rasulullah dahulu melakukan perjanjian dengan bani Dhamrah dari kabilah Arab. Isi perjanjian tersebut adalah: "Inilah surat Muhammad Rasulullah untuk bani Dhamrah; bahwa mereka dalam keadaan aman-harta dan jiwa mereka. Mereka mendapat bantuan dalam menghadapi orang yang memukul mereka, kecuali jika mereka memerangi agama Allah.”

2. Rasulullah juga pernah melakukan perikatan perjanjian dengan orang Yahudi untuk saling bertetangga dengan baik sejak beliau menetap di Madinah. Di bawah ini isi perjanjian tersebut: "Bismillahirrahmanirrahim (dengan nama Allah yang Maha Pengasih lagi Maha Penyayang). Ini surat dari Muhammad Rasululah, antara kaum muslimin dan mu'minin dari Quraisy dan penduduk Yatsrib serta orang-orang yang mengikuti mereka, sama-sama berjumpa dan berjuang. Sesungguhnya mereka adalah umat. Di luar golongan orang lain." 35

\section{Konsep Perjanjian dan Perikatan dalam Hukum Islam}

Perjanjian adalah sarana hukum terpenting yang pernah dikembangkan untuk menjamin keamanan ekonomi dan kestabilan masyarakat. Setiap orang terlibat

32 Ibid., hlm. 16.

33 Subekti, Pokok-Pokok Hukum Perdata, cet. XXVII (Jakarta; Intermasa, 1995), hlm. 122.

34 P. N. H. Simanjuntak, Pokok-Pokok Hukum Perdata Indonesia (Jakarta: Djambatan, 1999), hlm. 331.

35 Sayyid Sabiq, Fikih Sunnah, diterjemahkan oleh Kamaluddin A. MArzuki ( Bandung: AlMa'arif, 1987), hlm. 183. 


\section{Diskursus Konsep dan Prinsip Akad dalam Hukum Islam}

dengan perikatan dan perjanjian yang lahir dari padanya dalam berbagai aspek kehidupan. Oleh karenanya, perjanjian merupakan salah satu sumber perikatan yang terpenting.

Dalam hukum Islam ada beberapa istilah yang mengandung konsep perikatan.

1. Ditemukan istilah "hukum akad". Sebenarnya apa yang dimaksud dengan hukum akad itu tidak lain daripada akibat hukum yang timbul dari suatu perjanjian.

2. Para fuqaha' di berbagai tempat membahas apa yang mereka sebut al-amn, yang dapat diperbandingkan dengan hukum perikatan dalam hukum barat. Maksud al-amn adalah tanggung jawab seseorang untuk tidak melakukan sesuatu yang tidak merugikan orang lain. Bila ia melakukan perbuatan merugikan itu maka ia wajib membayar ganti rugi.

3. Para ahli hukum Islam klasik juga memakai al-iltizam untuk menjelaskan perikatan-perikatan yang timbul dari kehendak sepihak dan kadang-kadang perikatan yang timbul dari perjanjian. ${ }^{36}$

Berdasarkan pada hubungan-hubungan hukum yang terpisah-pisah, dalam kaitannya dengan objeknya, secara garis besar perikatan dapat dibagi menjadi: perikatan hutang (al-iltizam bi ad-dain), perikatan benda (al-iltizam bi al-'ain), perikatan melakukan sesuatu (al-iltizam bi al'amal), dan perikatan menjamin (al-iltizam bi attausiq). ${ }^{37}$

Meminjam pandangan ahli-ahli hukum barat; ahli hukum Islam seperti AzZarqa', menyebut sumber-sumber (mashadir al-iltizam) dalam Islam ada lima macam yaitu:

1. Akad ('aqad);

2. Kehendak sepihak (al-iradah al-munfaridab);

3. Perbuatan merugikan (al-fi'l ad-dar);

4. Perbuatan bermanfaat (al-fi'l an-nafi');

36 Syamsul Anwar, Teori Kausa dalam Hukum Islam (Suatu Kajian Asas Hukum), proyek perguruan tinggi agama Islam IAIN Sunan Kalijaga Yogyakarta tahun 1999/2000, hlm. 36-39.

${ }^{37}$ Ibid., hlm. 40. 


\section{Syara. ${ }^{38}$}

Seperti halnya dalam hukum barat; akad (perjanjian) dalam hukum Islam merupakan sumber paling penting bagi perikatan. Az-Zuhaili memberikan definisi akad dengan makna: "pertemuan ijab dan kabul yang dibenarkan oleh syara' yang menimbulkan akibat bukum terhadap objeknya". 39

\section{Macam-macam Akad (perjanjian)}

Para ahli hukum Islam berbeda pendapat dalam membagi jenis-jenis akad dalam syari'at Islam, perbedaan ini berdasarkan dari segi obyek akad. Walaupun terdapat perbedaan pendapat, dapat dikemukakan secara umum jenis-jenis akad dalam syari'at Islam, diantaranya:

1. Dilihat dari segi ada atau tidaknya qismah (pembagian) pada akad tersebut, maka dari segi ini akad terbagi pada:

a. A'qad Musamma yaitu akad-akad yang telah diberikan namanya oleh syara' dan ditetapkan untuknya hak-hak tertentu. A'qad Musamma ini ada dua puluh lima macam diantaranya: jual beli (ba’i), ijarah (sewa menyewa), rahn (gadai), syirkah, mudharabah, muzara'ah, dan lain-lain.

b. A'qad Ghairu Musamma yaitu akad-akad yang tidak diberikan namanya secara tertentu dan tidak ditentukan hukum-hukumnya oleh syara'. ${ }^{40}$

Para ahli hukum Islam, sepakat membagi akad dengan akad bernama dan tidak bernama. Menurut Al-Kasani ada beberapa akad muamalat bernama ada 18, sebagaimana berikut: sewa menyewa (ijarah), penempaan (al-istishna'), jual beli (al-ba'i), penanggungan (al-kafalab), pemindahan hutang (biwalah), pemberian kuasa (al-wakalah), perdamaian (as-sulh), persekutuan (asy-syirkah), bagi hasil (al-mudharabah), hibah (al-bibab), gadai (ar-rahn), penggarapan tanah (al-muzara'ab), pemeliharaan tanaman (al-

${ }^{38}$ Musthafa Ahmad Az-Zarqa', Al-Madkhal al-Figh al-'Am (Beirut: Dar al-Fikr, t.t.), II: 86.

${ }^{39}$ Wahbah az-Zuhaili, Al-Fiqh al-Islami wa Adillatubu (Beirut: Dar al-Fikr, 1989), IV: 81. 1999), hlm. 93

${ }^{40}$ T. M. Hasbi ash-Shiddieqy, Pengantar Figh Mua'amalat (Semarang: PT Pustaka Rizki Putra, 


\section{Diskursus Konsep dan Prinsip Akad dalam Hukum Islam}

musaqab), penitipan (al-wadi'ab), pinjam pakai (al-'ariyab), pembagian (alqismah), wasiat-wasiat (al-washaya), perhutangan (al-qardh). ${ }^{41}$

Ahli hukum klasik lainnya menyebutkan beberapa jenis akad lain lagi sehingga secara keseluruhan menurut perhitungan Az-Zarqa' mencapai 25 akad khusus. $^{42}$

Pertanyaan yang muncul adalah; apakah akad selain akad bernama diakui dalam hukum Islam? Dengan kata lain apakah terdapat kebebasan berkontrak dalam hukum Islam, baik untuk membuat akad bernama maupun mengisikan klausula-klausula yang mencerminkan masingmasing pihak? Pada dasarnya dapat dikatakan bahwa hukum Islam mengakui adanya kebebasan berkontrak. Nas-nas al-Qur'an dan sunnah Nabi serta kaidah-kaidah fiqh menunjukkan bahwa hukum Islam menganut asas kebebasan berkontrak. Dalam al-Qur'an Allah berfirman: "wahai orang-orang yang beriman penubilab akad-akad". 43 Dari ayat ini disimpulkan tentang adanya kebebasan berkontrak dalam hukum Islam. Perintah dalam ayat ini menunjukkan wajib, dan memenuhi akad-akad itu hukumnya wajib. sehingga dari ayat ini dapat disimpulkan bahwa akad apa saja baik yang bernama maupun yang tidak bernama wajib untuk dipenuhi. Dalam hadis Nabi dinyatakan: "orang-orang muslim itu terikat pada syarat-syarat (janji-janji) mereka". ${ }^{4}$

Kaidah fiqh juga mengatakan "pada dasarnya akad itu adalah kesepakatan kedua belah pibak dan akibat hukumnya adalah apa yang mereka ikatkan diri mereka melalui janji"." Kaidah ini jelas menunjukkan kebebasan berkontrak karena perjanjian itu dinyatakan berdasarkan kesepakatan kata sepakat para pihak dan akibat hukumnya adalah apa yang dibuat oleh para pihak itu sendiri melalui janji. ${ }^{46}$

2. Dilihat dari segi sifat dan hukumnya, akad terbagi pada:

${ }^{41}$ Abd ar-Razaq as-Sanhuri, Nadzariyyah al- $U$ qud (Beirut: Dar al-Fikr, t.t.), hlm. 87.

${ }^{42}$ Musthafa Ahmad Az-Zarqa', Al-Madkhal..., I: 538.

43 Al-Maidah (5): 1

${ }^{44}$ Al-Hakim, Al-Mustadrak (Riyadh: Maktabah wa Matabi' an-Nasyr al-Hadisah, t.t.), II:49.

45 Asmuni A Rahman, Qaidah-qaidah Figh (Jakarta: Bulan Bintang, 1975), hlm. 44.

${ }^{46}$ Kuat Ismanto, Asuransi Syariah: Tinjauan Asas-asas Hukum Islam (Yogyakarta: Pustaka Pelajar, 2009), hlm. 140-143. 
a. Akad sah, yaitu akad yang halal dan memenuhi rukun serta syaratsyaratnya dan juga tidak terdapat satu sifat apapun yang menyebabkan batalnya akad tersebut. ${ }^{47}$ Dalam akad sah, ketentuan-ketentuan yang merupakan akibat hukumnya terjadi dengan seketika, kecuali jika ada syarat yang lain. Misalnya, dalam akad jual beli yang sah; setelah terjadi ijab qabul maka barang yang di jual menjadi milik pembeli dan harga penjualan barang menjadi milik penjual kecuali apabila ada syarat khiyar. ${ }^{48}$ Akad sah dapat dibagi menjadi beberapa macam, akad sah yang dapat dilaksanakan tanpa bergantung kepada hal-hal lain disebut akad nafiz, dan akad sah yang pelaksanaannya bergantung kepada hal-hal lain disebut dengan akad manquf. Akad nafiz. merupakan akad yang terjadi antara pihak-pihak yang mempunyai kecakapan dan mempunyai kekuasaan melakukan akad, baik kekuasaan itu asli atau atas nama orang lain. Misalnya akad yang dilakukan oleh orang yang berakal sehat dan telah dewasa atas nama diri sendiri menyangkut harta benda yang dimiliki sendiri pula; atau akad yang diadakan oleh wali atas nama orang yang berada di bawah perwaliannya; atau akad yang dilakukan oleh wakil yang mendapat kuasa dari orang yang diwakilkan. Akad nafiz mempunyai akibat hukum tanpa bergantung kepada izin orang lain. Apabila akibat hukumnya terjadi seketika setelah akad dilakukan disebut dengan akad munjaz: Namun jika akibat hukumnya terjadi setelah beberapa waktu kemudian disebut dengan akad bersandar (mudhaf) kepada waktu mendatang. Sementara itu akad mauquf ialah akad yang terjadi dari orang yang memenuhi syarat kecakapan, tetapi tidak mempunyai kekuasaan melakukan akad, seperti akad yang dilakukan oleh anak tamyiz. Akad manquf hanya mempunyai akibat hukum apabila

${ }^{47}$ Zahri Hamid, Asas-asas Mu'amalah, hlm. 12.

${ }^{48}$ Ahmad Azhar Basyir, Asas-asas Hukum Mu'amalat.., hlm. 114. 


\section{Diskursus Konsep dan Prinsip Akad dalam Hukum Islam}

mendapat izin secara sah dari orang yang mempunyai kekuasaan melakukan akad. ${ }^{49}$

b. Akad tidak sah, yaitu akad yang tidak memenuhi rukun dan syaratnya, atau terdapat sifat yang menyebabkan batalnya akad tersebut. ${ }^{50}$ Akad tidak sah dibagi menjadi dua; yaitu akad yang rusak (fasid) dan akad yang batal (batil). ${ }^{51}$ Akad yang rusak yaitu akad yang tidak sempurna, yakni terdapat padanya sebagian syarat yang berpautan bukan dengan hukum pokok; seperti menjual sesuatu dengan harga yang tertentu tetapi ditangguhkan masa pembayarannya pada masa yang tidak ditentukan. ${ }^{52}$ Sedangkan akad yang batal adalah yaitu akad yang dianggap ajaran syari'at tidak diberlakukan padanya segala konsekuensi yang ada pada akad yang sah, seperti akad orang gila, anak kecil yang belum baligh, atau akad usaha terhadap barang yang haram (daging babi, bangkai, darah dan lain-lain). Atau akad yang secara asal disyari'atkan, tetapi secara aplikatif tidak disyari'atkan seperti akad orang yang di bawah paksaan. ${ }^{53}$

3. Dilihat formalitas dan dari bentuk atau cara melakukan akad. Dari sudut ini akad dibagi pada:

a. Akad-akad yang tunduk pada syarat-syarat formalitas yang ditentukan oleh pembuat hukum, di mana apabila syarat-syarat itu tidak terpenuhi akad tidak sah. Contohnya akad di luar lapangan harta

49 Pembagian akad sah kepada akad nafiz dan akad manquf disepakati para ulama mazhab Hanafi dan Maliki. Para ulama mazhab Syafi'I hanya memandang akad nafiz sebagai akad sah, sebab sebagian syarat akad sah menurut ulama mazhab Syafi'I ialah oang yang melakukan akad harus mempunyai kekuasaan melakukan akad. Mazhab Syafi'I tidak menyetujui akad mauquf menjadi bagian dari akad sah. Ibid..., hlm. 117-119.

50 Zahri Hamid, Asas-asas Mu'amalah, hlm. 18.

51 Pembagian akad tidak sah menjadi akad rusak dan akad batal berdasarkan pendapat dari ulama mazhab Hanafiyah. Sedangkan para ulama mazhab lain berpendapat akad tidak sah adalah akad yang sama sekali tidak pernah dipandang terjadi dan oleh karenanya tidak mempunyai akibat hukum. Demikian pula akad yang tidak memenuhi syarat-syarat akad yang sah. Akad tidak sah sama saja artinya dengan akad yang rusak atau akad yang batal. Dikutip dari Ahmad Azhar Basyir, Asas-asas Hukum Mu'amalat.., hlm. 113. Bandingkan dengan Abu Zahrah, Al-Milkiyah wa Nazariyyah al-'Aqd fi asy-Syari'ah al-Islamiyyah (Kairo: Dar al-Fikr al-'Araby, t.t.), hlm. 409.

${ }^{52}$ T. M. Hasbi ash-Shiddieqy, Pengantar Fiqh Mua'amalat, hlm. 110.

53 Abdullah al-Mushlih dan Shalah ash-Shawi, Fikib Ekonomi Kenangan Islam, penerjemah Abu Umar Basyir (Jakarta: Darul Haq, 2004), hlm. 37. 
hukum kekayaan, yaitu akad nikahdi mana di antara formalitas yang disyaratkan adalah kehadiran dan kesaksian dua orang saksi.

b. Akad konsensuil, yaitu jenis akad yang untuk terciptanya cukup berdasarkan pada kesepakatan para pihak tanpa diperlukan formalitasformalitas tertentu. Meskipun kadang-kadang yang dipersyaratkan adanya formalitas tertentu, seperti harus tertulis, hal tersebut tidak menghalangi keabsahan akad tersebut, dan tetap dianggap sebagai akad konsensuil.

c. Akad riil, yaitu akad yang untuk terjadinya diharuskan adanya penyerahan tunai objek akad, di mana akad tersebut belum terjadi dan belum menimbulkan akibat hukum apabila dilaksanakan. Ada lima macam jenis akad yang termasuk dalam kategori akad ini yaitu hibah, pinjam pakai, penitipan, kredit (utang) dan akad gadai. ${ }^{54}$

d. Akad ridla'iyah yaitu akad-akad yang tidak memerlukan upacara apabila terjadi persetujuan kedua belah pihak telah menghasilkan akad. Seperti jual beli tidak perlu dilakukan di kantor, dihadapan pejabat. $^{55}$

4. Dilihat dari akibat hukumnya, akad terbagi pada:

a. Berdasarkan tujuan akad, tujuan akad bermacam-macam; ada akad yang bertujuan memberikan hak milik kepada orang lain baik berupa benda maupun manfaat benda, baik dengan imbalan maupun tanpa imbalan, seperti pinjam-meminjam barang, jual beli, sewa menyewa dan lain sebagainya. Akad macam ini di sebut akad pemberian hak milik. Pemberian hak milik dengan imbalan disebut dengan akad tukar menukar (mu'awadah), sedangkan hak milik tanpa imbalan disebut dengan akad kebajikan (tabarru').

b. Akad yang berbentuk melepaskan hak tanpa ataupun dengan ganti disebut dengan akad pelepasan hak (isqat). Misalnya ibra', yaitu membebaskan pihak berutang dari kewajiban membayar hutang, 
membebaskan hukuman qishash terhadap pembunuh dengan sengaja, tetapi dengan ganti diyat dan sebagainya.

c. Apabila akad bertujuan melepaskan kekuasaan untuk melakukan sesuatu perbuatan kepada orang lain, akad semacam ini disebut akad pelepasan kekuasaan (ithlaq). Misalnya, orang memberi kuasa kepada seseorang untuk bertindak atas nama orang yang diwakilkan. Berarti, orang yang diwakilkan itu melepaskan ikatan tangannya kepada orang lain untuk dapat berbuat atas namanya.

d. Apabila akad bertujuan sebaliknya, yakni mengikat orang dari wewenang berbuat yang semula dimilikinya, disebut akad pengikat (taquid). Misalnya orang yang menghentikan kekuasaan wakilnya yang bertindak atas namanya.

e. Akad yang bertujuan bekerjasama untuk memperoleh sesuatu hasil atau keuntungan disebut dengan akad perserikatan (syirkab). Misalnya, persekutuan bagi untung rugi, bagi hasil dan sebagainya.

f. Akad yang bertujuan untuk memperkuat akad lain, seperti akad gadai sebagai penguat akad utang-piutang; disebut dengan akad pertanggungan (dhama, takmin, dan tautsiq). ${ }^{56}$

Sedangkan menurut Ahmad Muhammad al-'Assal dan Fathi Ahmad Abdul Karim akad itu terbagi kepada:

Pertama, akad jual beli; yakni akad memiliki harta dengan menukarkannya pada harta lain dengan suka rela. Harta yang ditukarkan haruslah merupakan harta yang halal, bernilai, dan dapat diserahkan. ${ }^{57}$ Jual beli yang termasuk pada akad ini adalah jual beli mabrur, yaitu jual beli yang berlangsung antara barang-barang yang halal, jauh dari perkara yang haram, dan tidak termasuk salah satu jenis akad-akad riba ataupun akad-akad majbul yang menyebabkan terjadinya spekulasi harga atau

${ }^{56}$ Zahri Hamid, Asas-asas Mu'amalah ..., hlm. 123-124.

${ }^{57}$ Ahmad Muhammad al-'Assal dan Fathi Ahmad Abdul Karim, An-Nizam al-Iqtishadi fi alIslam: Mabadi'ubu wa Ibdafubu (Kairo: Maktabah Wahbah, 1397 H/1977 M), hlm. 174. 


\section{Diskursus Konsep dan Prinsip Akad dalam Hukum Islam}

barang. Jual beli mabrur menjauhi cara-cara usaha yang kotor, seperti berdagang dalam perkumpulan foya-foya, perjudian ataupun undian, dan sejenisnya. ${ }^{58}$

Kedua, akad salam; as-Salam berarti meminjamkan barang atau harga tertentu. Maksudnya adalah perjanjian menanggung (penjual) akan menyerahkan barang di masa yang akan datang, sebagai penukar dari pembayaran yang telah ia terima. Ada beberapa syarat dalam akad as-Salam ini yaitu: akad salam harus pada barang-barang yang sifatnya mungkin dijangkau, seperti biji-bijian atau yang lainnya yang dapat ditimbang dan disukat; barang tersebut harus dikatkan dengan jelas jenisnya seperti untuk kurma ada jenis burni atau maklaqi dan sebagainya; disebutkan (harus jelas) ukurannya dan timbangannya. ${ }^{59}$

Ketiga, akad-akad syirkah, ${ }^{60}$ ada empat macam:

a. Syirkah 'Inan yaitu persekutuan dalam urusan harta oleh dua orang, bahwa mereka akan memperdagangkan dengan keuntungan dibagi dua. Pada syirkah inan ini jumlah modal dari pihak-pihak yang melakukan akad boleh berbeda. Dengan demikian dibolehkan salah seorang diantara mereka mengeluarkan modal lebih banyak dari yang lain. Dan boleh pula salah satu pihak sebagai penanggung jawab; sedangkan pihak yang lainnya tidak. Diperbolehkan dalam syirkah ini keuntungan sama, boleh pula berbeda, sesuai dengan kesepakatan mereka berdua. Jika mengalami kerugian, maka persentasenya ditinjau dari persentase modal ${ }^{61}$

b. Syirkah Wujuh yaitu bahwa dua orang atau lebih membeli sesuatu tanpa permodalan, kerjasama jenis ini terkait dengan reputasi atau nama baik salah satu pihak yang berakad dan pihak yang "dipinjam" nama baiknya ini tidak menyetorkan modal dengan nominal tertentu. Namun, walaupun salah satu pihak tidak menyetorkan modal, keuntungan dari kerjasama ini

${ }^{58} \mathrm{Al}-\mathrm{Maidah}(5):$ 90-91.

59 Ahmad Muhammad al-'Assal dan Fathi Ahmad Abdul Karim, An-Nizam al-Iqtishadi..., hlm. 176-177.

${ }^{60}$ Kasani memberikan definisi syirkah yaitu partisipasi antara dua orang atau lebih dalam bisnis tertentu dengan penetapan modal yang sama dan menurut kesepakatan bersama yang melaksanakan bisnis serta membagi keuntungan dan kerugian sesuai dengan proporsi yang ditentukan. Di kutip dari Kasani, 'Ala aal-Din, Badaa'i al-Sanaa'i, juz VI, (Mesir, Mathba'ah Abu Bakar bin Mas'ud Jamaliyah, t.t), hlm. 22.

${ }^{61}$ Sabiq, Sayyid, Fikih Sunnah, alih bahasa oleh Kamaluddin A. Marzuki, jilid 13, Bandung, PT al-Ma'arif, 1997, hlm. 175-176. 
tetap sama-sama dibagi sesuai dengann isi akad. Syirkah ini dinamakan juga dengan syirkah tanggung jawab. ${ }^{62}$

c. Syirkah Abdan yaitu dua orang atau lebih mengadakan perseroan dalam bentuk usaha, tapi hanya mengandalkan fisik dan tenaganya seperti dalam suatu industri konveksi, penatu, tukang kayu, tukang besi dan sebagainya; dan apa saja yang dapat dilakukan oleh dua orang pesero ini yang hasilnya dibagi dua atau dibagi berdasarkan ketentuan kesepakatan berdua.

d. Syirkah Mufawadhah yaitu bergabungnya dua orang atau lebih untuk melakukan kerjasama dalam suatu urusan. Dengan ketentuan syarat-syarat samanya modal masing-masing, seandainya salah satu partner memiliki lebih banyak permodalan, maka syirkah tersebut tidak sah, mempunyai wewenang bertindak yang sama, maka tidak sah syirkah antara anak kecil dengan orang yang sudah baligh, bahwa masing-masing menjadi penjamin atas lainnya terhadap apa yang ia beli dan ia jual; seperti salah seorang menjadi wakil maka tidak dibenarkan salah satu diantara mereka mempunyai wewenang lebih dari yang lainnya. ${ }^{63}$

Keempat, akad muzara'ah yaitu suatu akad keuntungan antara pemilik lahan dengan penggarap lahan dan ditentukan bagi hasil yang disepakati oleh kedua pihak (pemilik lahan dan penggarap lahan) pada waktu akad. ${ }^{64}$ Muzara'ah hukumnya boleh menurut pendapat para ulama. Muzara'ah sudah menjadi pekerjaan kaum muslimin sejak masa Nabi dan pada masa khulafaurrasyidin. Muzara'ah merupakan pendapat para pembesar sahabat Nabi seperti Ibn Mas'ud, dan juga pendapat Ahmad bin Naval, Abu Yusuf, dan lain-lain. ${ }^{65}$

Kelima, akad ijarah yaitu akad yang lazim dari kedua belah pihak yang berakibat pihak yang menyewakan berhak memiliki upah dan pihak si penyewa berhak memiliki manfaat, kecuali bila barang yang dimanfaatkan itu cacat sehingga mengurangi manfaatnya. Ijarah hanya sah dengan syarat-syarat mengetahui manfaatnya, mengetahui berapa sewa atau upahnya, dan manfaat itu harus halal; jadi

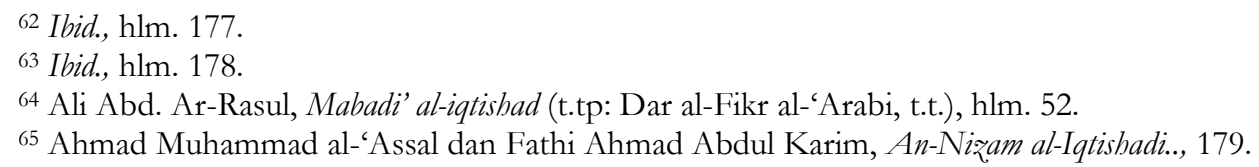




\section{Diskursus Konsep dan Prinsip Akad dalam Hukum Islam}

tidak sah mengupah perzinaan, seruling, menyanyi, menyewa rumah untuk dijadikan gereja, untuk tempat berjudi, dan lain-lain. ${ }^{66}$

Dari segi ada atau tidaknya kompensasi, fiqh mu'amalat membagi akad menjadi dua bagian, yaitu akad tabarru' dan akad tijarah (mu'awadah).

1. Akad tabarru' (gratuitous contract) adalah akad untuk tujuan sosial dan mengenyampingkan profit bisnis. ${ }^{67}$ Transaksi ini pada hakikatnya bukan transaksi bisnis untuk mencari keuntungan komersil. Akad tabarru' ini tujuannya adalah untuk membantu (tabarru' akar katanya adalah birr yang dalam bahasa Arab bermakna kebaikan). Dalam akad tabarru', pihak yang berbuat kebaikan tersebut tidak berhak mensyaratkan imbalan apapun kepada pihak lainnya. Imbalannya dari Allah bukan dari manusia. Contoh akad-akad tabarru' adalah qard, rahn, biwalah, wakalah, kafalah wadi'ah, bibah, wakaf, shadaqah, hadiab dan lain-lain.

Ada tiga bentuk umum akad tabarru', yakni:

a. Meminjamkan uang (lending \$)

Akad meminjamkan uang ini ada tiga jenis. Jika pinjaman ini diberikan tanpa mensyaratkan apapun dan hanya untuk meminjamkan uang dan ketika sudah jatuh tempo uang tersebut harus dikembalikan oleh peminjam kepada yang memberikan pinjaman, maka bentuk meminjamkan uang seperti ini disebut qard. ${ }^{68}$

Selanjutnya, jika yang meminjamkan uang memberikan syarat tertentu kepada peminjam, misalnya meminta jaminan sesuai dengan jumlaah

66 Ahmad Muhammad al-'Assal dan Fathi Ahmad Abdul Karim, Sistem, Prinsip dan Tujuan Ekonomi Islam, alih bahasa oleh Imam Saefudin (Bandung: Pustaka Setia, 1999), hlm. 223.

${ }^{67}$ Secara umum organisasi nirlaba (not profit organization) adalah suatu institusi yang dalam menjalankan operasinya tidak berorientasi mencari laba. Namun demikian, bukan berarti organisasi nirlaba tidak dibolehkan menerima dan menghasilkan keuntungan dari setiap aktivitasnya. Hanya biasanya jika memperoleh keuntungan. Keuntungan tersebut dipergunakan untuk menutup biaya operasional. Keuntungan tersebut dipergunakan untuk menutup biaya operasional atau kembali disalurkan untuk kegiatan utamanya lagi. Dikutip dari Hertanto Widodo dan Teten Kustiawan, Akuntansi dan Manajemen Keuangan Untuk. Organisasi Pengelola Zakat (Jakarta: Institut Manajemen Zakat, 2001), hlm.4.

${ }^{68}$ Istilah qard ini berbeda dengan qard hasan. Qard adalah akad untuk meminjamkan uang. Sedangkan qard hasan pada hakikatnya adalah sedekah, karena akad ini tidak mensyaratkan bahwa uang yang diberikan harus dikembalikan. Dikutip dari Adiwarman Karim, Bank Islam Analisis Fiqib dan Kenangan, edisi dua (Jakarta: PT Raja Grafindo Persada, 2004), hlm. 58-60. 
pinjaman yang diberikan, maka bentuk pemberian pijaman seperti ini disebut dengan rabn.

Ada lagi suatu bentuk pemberian pinjaman uang, dimana tujuannya adalah untuk memindahkan piutang dari satu pihak ke pihak lain. Maka, bentuk peminjaman uang ini disebut biwalah.

b. Meminjamkan jasa (lending yourself)

Akad meminjamkan jasa juga terbagi tiga jenis. Bila meminjamkan "diri" (yakni jasa keahlian, keterampilan dan sebagainya) untuk melakukan sesuatu atas nama orang lain, maka hal itu disebut wakalah. Karena melakukan sesuatu atas nama orang yang dibantu tersebut, sebenarnya yang meminjamkan "diri”-nya tersebut menjadi wakil orang itu.

Selanjutnya, bila akad wakalah ini dirinci tugasnya, yakni bila menawarkan jasa untuk menjadi wakil seseorang, dengan tugas menyediakan jasa penitipan dan pemeliharaan, maka bentuk pinjaman seperti ini disebut akad wadi'ah. Ada variasi lain dari akada wakalah, yakni contingent wakalah (wakalah bersyarat). Dalam hal ini, memberikan jasa melakukan suatu perbuatan yang mengatasnamakan orang lain, jika terpenuhi kondisinya atau jika sesuatu terjadi. Wakalah bersyarat ini dalam terminologi fiqh disebut akad kafalah.

c. Memberikan sesuatu (giving something)

Akad memberikan sesuatu ini terbagi pada hibah, wakaf, sedekah, hadiah dan lain-lain. Dalam semua akad-akad tersebut, si pelaku memberikan sesuatu kepada orang lain. Bila penggunaannya untuk kepentingan umum dan agama, akadnya dinamakan wakaf. Objek wakaf ini tidak boleh diperjualbelikan. Sedangkan hibah dan hadiah adalah pemberian sesuatu secara sukarela kepada orang lain.

Akad yang awal mulanya untuk tujuan kebajikan (tabarru') di tengah waktu pejanjian ketika akad belum berakhir tidak boleh dirubah menjadi akad 
komersil (tijarah), namun sebaliknya, jika akad komersil ingin dirubah menjadi akad kebajikan ketika masa akad belum berakhir tidak menjadi masalah. ${ }^{69}$

\section{Akad Tijarah}

Akad tijarah atau mu'awadah (compensational contract) adalah segala macam perjanjian yang menyangkut for profit transaction. Akad-akad ini dilakukan dengan tujuan mencari keuntungan, karena itu bersifat komersil. Diantara akad tijarah adalah akad-akad investasi, jual-beli, sewa-menyewa, dan lainlain.

Akad tijarah dapat kita bagi menjadi dua, yaitu:

a. Natural Certainty Contract

Dalam Natural Certainty Contract, kedua belah pihak saling mempertukarkan aset yang dimilikinya, karena itu objek pertukarannya (baik barang maupun jasa) pun harus harus ditetapkan di awal akad dengan pasti, baik jumlahnya maupun mutunya, harganya, dan waktu penyerahannya. Jadi kontrak-kontrak ini menawarkan return yang tetap dan pasti. Yang termasuk dalam kategori ini adalah kontrak-kontrak jual-beli (dalam bentuk al-ba'i naqdan, al-ba'i muajjal, salam, dan istishna), upah-mengupah, sewa-menyewa (dalam bentuk ijarah dan ijarah muntabiya bi at-tamlike) dan lain-lain.

b. Natural Uncertainty Contract

Dalam Natural Uncertainty Contract, pihak-pihak yang bertransaksi saling mencampurkan asetnya (baik real asset maupun financial asset) menjadi satu kesatuan dan saling berbagi risiko jika terdapat kerugian serta berbagi keuntungan sesuai dengan isi akad. Jadi, untung dan rugi ditanggung bersama oleh pihak yang berakad. Kontrak ini diawal akadnya belum bisa menggambarkan kepastian untung dan rugi dari bisnis yang dijalankan. Termasuk dalam kontrak ini adalah kontrakkontrak investasi. Kontrak ini tidak menawarkan return yang tetap dan pasti. Jadi sifatnya fixed and predetermined. Yang termasuk dalam Natural

${ }^{69}$ Ibid., hlm. 60-61. 
Diskursus Konsep dan Prinsip Akad dalam Hukum Islam

Uncertainty Contract ini adalah musyarakah, muzara'ah, musaqah, dan mukhabarah. ${ }^{70}$

\section{E. Prinsip-prinsip Penyelenggaraan Akad (perjanjian)}

Dalam masa pembangunan, dengan kemajuan teknologi, khususnya dalam bidang komunikasi membawa akibat terhadap frekuensi hubungan orang yang satu dengan yang lainnya, terutama dalam lapangan bisnis meningkat dengan pesatnya. Sadar atau tidak sebagian besar dari hubungan tersebut merupakan hubungan hukum yang berwujud perjanjian. Dan dengan perkembangan frekuensi yang meningkat tersebut; model dan bentuk perjanjianpun berkembang dengan mempertimbangkan faktor ekonomi pula.

Dalam hukum Islam sendiri, terdapat prinsip-prinsip dan ketentuanketentuan yang mengelilingi gerak roda kegiatan mu'amalah, khususnya perjanjian yang dapat dirumuskan sebagai berikut: ${ }^{71}$

Pertama, pada dasarnya segala bentuk mu'amalah adalah mubah, ${ }^{72}$ kecuali yang ditentukan lain oleh al-Qur'an dan sunnah Rasul. Dalam kaidah fiqh dinyatakan

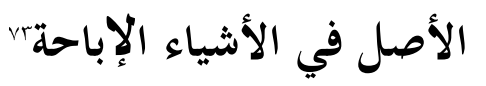

Prinsip ini mengandung arti bahwa hukum Islam memberi kesempatan luas terhadap perkembangan bentuk dan macam mu'amalat baru yang sesuai dengan perkembangan kebutuhan hidup masyarakat.

Kedua, mu'amalah dilakukan atas dasar suka rela, tanpa mengandung unsurunsur paksaan. Dalam haditsnya Rasulullah bersabda:

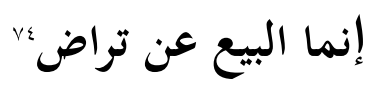

\footnotetext{
${ }^{70}$ Ibid., hlm. 64-67.

${ }^{71}$ Zahri Hamid, Asas-asas Mu'amalah, hlm. 15-16.

${ }^{72}$ Frank e. Vogel dan Samuel L. Hayes, Islamic Law and Finance: religion, Risk, and Return (London, Boston: Kluwer Law International, 1998), hlm. 98.

${ }^{73}$ Al-Imam Murjalal ad-Din 'Abd. Ar-Rahman as-Suyuthi, al-Asybah wa an-Naz̧hair fi Qawaid Fiqh asy-Syafi'iyyah (Singapura: Sulaiman Mar'I, t.t.), hlm. 66.

${ }^{74}$ Ibn Majah, Sunan Ibn Majah, “Abwab at-Tijarah", "Fashl Ba’i al-Khiyar”, cet.2 (Beirut: Dar al-Fikr, t.t.), II: 5. Hadits diriwayatkan dari al-'abbas bin al-Walid ad-Dimasyiqi.
} 


\section{Diskursus Konsep dan Prinsip Akad dalam Hukum Islam}

Islam memperingatkan agar kebebasan kehendak harus selalu dijunjung tinggi karena mengabaikaan kebebasan kehendak itu berakibat dapat merusak mua'amalat. Misalnya seseorang dipaksa menjual rumah kediamannya padahal ia masih ingin memilikinya dan tidak ada hal yang mengharuskan ia menjual rumah tersebut dengan kekuatan hukum.

Selanjutnya ditegaskan lagi oleh Ahmad Azhar Basyir bahwa rusaknya suatu akad dikarenakan tidak terpenuhinya unsur suka rela antara pihak-pihak yang bersangkutan. Jika ada paksaan, penipuan dan muslihat dalam akad tersebut, maka akad tersebut menjadi akad fasid. ${ }^{75}$

Suka rela (at-taradhi) secara bahasa berwazan at-tafa'ul memiliki faedah li musyarakah (saling melakukan sesuatu), yaitu rela sama rela dalam sesuatu. Sedangkan secara istilah fiqh at-taradhi berarti pertemuan antara ijab dan qabul yang saling mencocoki. ${ }^{76}$ Sedangkan secara istilah Muh. Hasan Qasim mendefinisikan at-taradhi dengan suka rela untuk melakukan akad jual beli yang bisa direalisasikan dengan menyertakan ijab dari salah satu pihak dari dua pihak yang mengadakan akad dengan adanya penerimaan (qabul) dari pihak lain. ${ }^{77}$

Dasar dari at-Taradhi ini secara khafi ${ }^{78}$ telah disebutkan dalam firman Allah (Q.S. an-Nisa' (4): 29), dan dalam kerelaan dalam bahasa yang berbeda yaitu (Q.S. anNisa' (4):4) ${ }^{79}$. Sedangkan dasar dari hadis Nabi adalah:

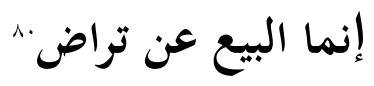

75 Ahmad Azhar Basyir, Asas-asas Hukum Mu'amalat.., hlm. 101.

${ }^{76}$ Muhammad Hasan Qasim, al-Mujaz fi 'Aqd al-Ba'I (Iskandariyah: Dar al-Jami'ah al-Jadidah, 1996), hlm. 59.

77 Ibid., hlm. 62. bandingkan dengan Samir 'Abd as-Sayyid, 'Aqd al-Ba'i (Iskandariyyah: AlFanniyah li at-Taba'ah wa an-Nasr, t.t.), hlm. 36. dan bandingkan juga dengan al-Imam Muhammad Abu Zahrah, al-Milkiyyah wa Nazariyyah al-'Aqd fi asy-Syari'ah al-Islamiyyah (t.tp: Dar al-Fikr al-'Araby, t.t.), hlm. 202-203 dan 321.

${ }^{78}$ Kalimat 'an taradin minkum dalam an-Nisa (4): 29 menurut dalalahnya termasuk nas khafi, karena arti istilah tersebut menjadi kabur jika ditearpkan ke dalam satuan-satuan yang lain, seperti attaradhi dalam akad yang terdapat unsur riba, gharar dan judi.

79 An-Nisa (4): 4. tafsir dari ayat tersebut adalah bahwa kewajiban bagi suami untuk memberikan mahar kepada isterinyadengan kemurnian jiwa dan kerelaan hati. Sebagaimana seseorang memberikan sesuatu kepada orang lain dengan tanpa menunggu imbalan darinya. Di kutip dari Muhammad Yusuf Musa, Fiqh al-Kitab wa as-Sunnab al-Buyu' wa al-Mu'amalat al-Mu'ashirah, cet.I (Kairo: Dar al-Kitabal-'Arabi, 1337 H/1954 M), hlm. 78.

${ }^{80}$ Ibn Majah, Sunan Ibn Majah...., hlm.5. 
Ketiga, Mu'amalah dilakukan atas dasar pertimbangan mendatangkan manfaat dan menghindari madharat dalam hidup masyarakat. Dalam kaidah fiqh dinyatakan:

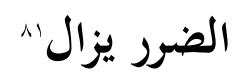

Prinsip yang ketiga ini mengingatkan bahwa suatu bentuk mu'amalah dilakukan atas dasar pertimbangan mendatangkan manfaat dan menghindari madharat dalam hidup bermasyarakat, dengan akibat bahwa segala bentuk mu'amalah yang merusak kehidupan masyarakat tidak dibenarkan. Misalnya berdagang narkotika, ganja, prostitusi, perjudian, dan lain-lain.

Keempat, mu'amalah dilaksanakan dengan memelihara nilai keadilan, menghindari unsur-unsur penganiayaan, unsur-unsur pengambilan kesempatan dalam kesempitan. Prinsip ini menentukan bahwa segala bentuk mu'amalah yang mengandung unsur penindasan tidak dibenarkan. Misalnya dalam hutang-piutang dan tanggungan barang untuk jumlah hutang yang jauh lebih kecil dari pada harga barang tanggungannya diadakan ketentuan; jika dalam waktu tertentu hutang tidak dibayar, barang tanggungan menjadi lebur, menjadi milik yang memberikan piutang. ${ }^{82}$

Dalam Kompilasi Hukum Ekonomi Syari'ah bab II pasal 21 akad dilakukan berdasarkan asas:

1. Ikbtiyari (sukarela); setiap akad dilakukan atas kehendak para pihak, terhindar dari keterpaksaan karena tekanan salah satu pihak atau pihak lain.

2. Amanah (menepati janji); setiap akad wajib dilaksanakan oleh para pihak sesuai dengan kesepakatan yang ditetapkan oleh yang bersangkutan dan pada saat yang sama terhindar dari cedera janji.

3. Ihtiyati (kehati-hatian); setiap akad dilakukan dengan pertimbangan yang matang dan dilaksanakan secara tepat dan cermat.

4. Luæum (tidak berubah); setiap akad dilakukan dengan tujuan yang jelas dan perhitungan yang cermat, sehingga terhindar dari praktik spekulasi atau maisir.

${ }^{81}$ Al-Imam Murjalal ad-Din 'Abd. Ar-Rahman as-Suyuthi, al- Asybah wa an-Naz̧hair..., hlm. 92.

${ }^{82}$ Ahmad Azhar Basyir, Asas-asas Hukum Mu'amalat.., hlm. 15-17. 
5. Saling menguntungkan; keberadaan akad adalah untuk menjembatani keinginan pihak-pihak yang berakad dan menjaga para pihak yang berakad dari penipuan dan kecurangan.

6. Taswiyah (kesetaraan); para pihak dalam setiap akad memiliki kedudukan yang setara, dan mempunyai hak dan kewajiban yang seimbang.

7. Transparansi; pihak yang berakad tidak ada yang menyimpan rahasia terkait dengan objek akad, sehingga harus ada saling terbuka diantara pihak yang berakad.

8. Kemampuan; akad tidak boleh dilakukan di luar kemampuan maupun kapasitas pihak yang berakad, sehingga tidak menjadi beban yang berkelebihan bagi yang bersangkutan.

9. Taisir (kemudahan); akad yang disepakati oleh para pihak yang berakad tidak memberikan beban dan menyulitkan pihak yang berakad.

10. Itikad baik; akad harus memberikan kemaslahatan dan kebaikan bagi pihak yang berakad.

11. Sebab yang halal; tidak bertentangan dengan hukum, tidak dilarang oleh hukum dan tidak haram.

12. Al-Hurriyah (kebebasan berkontrak)

13. Al-Kitabah (tertulis). ${ }^{83}$

Suatu pelaksanaan akad antara kedua belah pihak juga harus didasarkan pada prinsip: sukarela (ikhtiyari), menepati janji (amanab), kehati-hatian (ibtiyati), tidak berubah (luгum), saling menguntungkan, kesetaraan (taswiyah), transparansi, kemampuan, kemudahan (taisir), itikad baik dan sebab yang halal. Prinsip-prinsip tersebur sebenarnya hampir sama dengan asas hukum perjanjian berdasarkan hukum positif yang berlaku di Indonesia.

Perbedaan mendasar antara akad syari'ah dengan perjanjian konvensional adalah dalam akad syari'ah dianut prinsip yang tidak dianut oleh oleh hukum perjanjian pada hukum positif, yaitu:

1. Tidak berubah (konstan)

${ }^{83}$ Mahkamah Agung Republik Indonesia, Kompilasi..., hlm. 15-16. 
Maksudnya konstan di sini adalah mengenai nilai objek jual belinya (dalam hal perjanjian jual beli atau proporsi nisbah bagi hasil dalam hal perjanjian kerja sama bagi hasil). Pada konsep dasarnya, prinsip syari'ah tidak menganggap uang sebagai komoditas. Oleh karena itu, tidak dikenal adanya prinsip time value of money. Jadi, jumlah uang Rp 1 juta pada hari ini, dan uang Rp 1 juta tiga tahun mendatang, nilainya akan tetap sama.

2. Transparan

Transparan artinya tidak ada tipu muslihat, semua hak dan kewajiban masing-masing pihak diungkap secara tegas dan jelas dalam akad perjanjian. Pengungkapan hak dan kewajiban itu terutama yang berhubungan dengan risiko yang mungkin akan dihadapi masing-masing pihak. Misalnya, pada akad murabahah, bank syari'ah selaku penjual harus menyebutkan berapa harga pokok barang yang ditransaksikan dan berapa besar margin keuntungannya. ${ }^{84}$

\section{F. Kesimpulan}

Perjanjian (akad) merupakan awal timbulnya suatu perikatan antara dua orang atau lebih. Jika dua orang atau lebih sudah melakukan suatu perjanjian, maka kedua pihak tersebut sudah mempunyai hubungan hukum yang sama-sama harus dijaga oleh kedua pihak; karena jika perjanjian tersebut tidak dijaga akan menimbulkan wanprestasi akibat kelalaian salah satu pihak.

Prinsip-prinsip perjanjian (akad) dalam hukum Islam pada dasarnya diambil dari sumber-sumber hukum Islam itu sendiri yang kemudian diaplikasikan dalam bidang kehidupan sehingga menimbulkan berbagai persepsi tentang pembagian perjanjian (akad) berdasarkan pada obyek perjanjian (akad) itu sendiri.

Intinya dalam perjanjian (akad) ini, Islam menghendaki adanya kejujuran dalam perjanjian (tidak ingkar janji) seperti yang diperintahkan dalam surat al-Ma'idah (5) ayat 1 . Karena dalam perjanjian itu tergabung dimensi ibadah dan mu'amalah sebagai cakupan dari syariah.

${ }^{84}$ Irma Devita Purnamasari dan Suswinarno, Panduan Lengkap Hukum Praktis Populer Kiat-kiat Cerda, Mudah, dan Bijak Memahami Masalah Akad Syari'ah (Bandung: Kaifa, 2011), hlm. 4-5 


\section{Diskursus Konsep dan Prinsip Akad dalam Hukum Islam}

\section{DAFTAR PUSTAKA}

Anwar, Syamsul, Teori Kausa dalam Hukum Islam (Suatu Kajian Asas Hukum), proyek perguruan tinggi agama Islam IAIN Sunan Kalijaga Yogyakarta tahun $1999 / 2000$.

Hukum Perjanjian Syariab: Studi tentang Teori Akad dalam Fikih Muamalat, cet. ke-2, Jakarta: Rajawali Press, 2010

Basyir, Ahmad Azhar, Asas-asas Hukum Mu'amalat (Hukum Perdata Islam), Yogyakarta: Perpustakaan Fakultas Hukum UII, 1993

C.S.T. Kansil, Pengantar Ilmu Hukum dan Tata Hukum Indonesia, Jakarta: Balai Pustaka, 1986.

Dahlan, Abdul Aziz (ed.) et.al., Ensiklopedi Hukum Islam, cet.1, jilid I, Jakarta: Ichtiar Baru van Hoeve, 1996

Din, Kasani, 'Ala al-, Badaa'i al-Sanaa'i, juz VI, Mesir, Mathba'ah Abu Bakar bin Mas'ud Jamaliyah, t.t

Djamil, Faturrahman, "Hukum Perjanjian Syari'ah", dalam Kompilasi Hukum Perikatan oleh Mariam Darus Badrulzaman, et.al, cet.1, Bandung: Citra Aditya Bakti, 2001

Hakim, Al-, Al-Mustadrak, juz II, Riyadh: Maktabah wa Matabi’ an-Nasyr al-Hadisah, t.t.

Hamid, Zahri, Asas-asas Mu'amalah Tentang Fungsi Akad Dalam Masyarakat, Yogyakarta: IAIN Sunan Kalijaga, t.t.

H. F. A. Vollmar, Pengantar Studi Hukum Perdata, diterjemahkan oleh I.S. Adiwinarta, cet. III Jakarta: Rajawali Pers, 1992

Ismanto, Kuat, Asuransi Syari'ah: Tinjauan Asas-asas Hukum Islam, Yogyakarta: Pustaka Pelajar, 2009.

Jumu'ah, Ali bin Muhammad al-, Mu'jam al-Musthalahat al-Iqtishadiyah wa al-Islamiyah, Riyad: Maktabah al-'Abikan, 1421 H / 2000 M.

Karim, Adiwarman, Bank Islam Analisis Fiqib dan Keuangan, edisi dua, Jakarta: PT Raja Grafindo Persada, 2004.

Karim, Ahmad Muhammad al-'Assal dan Fathi Ahmad Abdul, An-Nizam al-Iqtishadi fi al-Islam: Mabadi'ubu wa Ibdafubu, Kairo: Maktabah Wahbah, 1397 H/1977 M. 
, Sistem, Prinsip dan Tujuan Ekonomi Islam, alih bahasa oleh Imam Saefudin, Bandung: Pustaka Setia, 1999.

K.R.M.T. Titodiningrat, Ikhtisar Hukum Perdata dan Hukum Dagang, Jakarta: Yayasan Pembangunan, 1952

Mahkamah Agung Republik Indonesia, Kompilasi Hukum Ekonomi Syari'ah, t.tp: t.tn, 2008.

Majah, Ibn, Sunan Ibn Majah, “Abwab at-Tijarah”, "Fashl Ba'I al-Khiyar”, cet.2, juz II, Beirut: Dar al-Fikr, t.t.

Mas'adi, Ghufron A., Fiqh Muamalah Kontekstual, cet. 1, Jakarta: Raja Grafindo Persada, 2002

Mertokusumo, Sudikno, Mengenal Hukum Suatu Pengantar, Yogyakarta: Liberty, 1986.

Munawwir, Ahmad Warson Al-Munawwir Kamus Arab Indonesia, Yogyakarta: PP alMunawwir Krapyak, 1984

Musa, Muhammad Yusuf, Figh al-Kitab wa as-Sunnah al-Buy' wa al-Mu'amalat alMu'ashirah, cet.I, Kairo: Dar al-Kitabal-'Arabi, 1337 H/1954 M.

Niazi, Liaquat Ali Khan, Islamic Law of Contract, Lahore: Research Cell, t.t.

P. N. H. Simanjuntak, Pokok-Pokok Hukum Perdata Indonesia, Jakarta: Djambatan, 1999.

Prodjodikoro, R. Wirjono, Asas-Asas Hukum Perjanjian, cet. XI, Jakarta: Sumur Bandung, 1989

Bandung, 1992

Asas-Asas Hukum Perdata, cet. 11, Jakarta: Sumur

Purnamasari, Irma Devita dan Suswinarno, Panduan Lengkap Hukum Praktis Populer Kiat-kiat Cerda, Mudah, dan Bijak Memahami Masalah Akad Syariah, Bandung: Kaifa, 2011

Pusat Pengkajian Hukum Islam dan Masyarakat Madani (PPHIMM), Kompilasi Hukum Ekonomi Syariah, edisi revisi, Jakarta: Kencana, 2009

Qasim, Muhammad Hasan, al-Mujaz fi 'Aqd al-Ba'I, Iskandariyah: Dar al-Jami'ah alJadidah, 1996

Rahman, Asmuni A., Qaidah-qaidah Fiqh, Jakarta: Bulan Bintang, 1975. 
Rasul, Ali Abd. Ar-, Mabadi' al-iqtishad, t.tp: Dar al-Fikr al-'Arabi, t.t..

R. Setiawan, Pokok-Pokok Hukum Perikatan, cet. IV, Bandung: Binacipta, 1990

Sabiq, Sayyid, Fikih Sunnah, diterjemahkan oleh Kamaluddin A. MArzuki, Bandung: Al-Ma'arif, 1987

Fikih Sunnah, alih bahasa oleh Kamaluddin A. Marzuki, jilid 13, Bandung, PT al-Ma'arif, 1997.

Sanhury, Abd. Ar-Razzaq as-, Nadzariyahal-'Aqd, Beirut: Dar al-Fikr, t.t.

Sayyid, 'Abd as-, 'Aqd al-Ba'I, Iskandariyyah: Al-Fanniyah li at-Taba'ah wa an-Nasr, t.t.

S. E. Rayner, The Theory of Contract in Islamic Law, London: Bordrecht/Boston: Graham and Trorman, 1991

Shawi, Abdullah al-Mushlih dan Shalah ash-, Fikih Ekonomi Kenangan Islam, diterjemahkan oleh Abu Umar Basyir, Jakarta: Darul Haq, 2004.

Shiddieqy, Muhammad Hasbi ash-, Pengantar Fiqh Muamalah, Semarang: Pustaka Rizki Putra, 1999

Subekti, Hukum Perjanjian, cet. XV, Jakarta: Intermasa, 1994

1995.

, Pokok-Pokok Hukum Perdata, cet. XXVII, Jakarta; Intermasa,

Suyuthi, Al-Imam Murjalal ad-Din 'Abd. Ar-Rahman as-, al- Asybah wa an-Nað̧hair fi Qawaid Figh asy-Syafi'iyyah, Singapura: Sulaiman Mar'I, t.t..

Syahnan, Mhd., Modernization of Islamic Law of Contract, Jakarta: Badan Litbang dan Diklat Departemen Agama RI, 2009.

Tjitrosudibio, R. Subekti dan R, Kitab Undang-Undang Hukum Perdata, cet.XXVIII, Jakarta: Pradnya Paramita, 1996

Utrecht, Pengantar Dalam Hukum Indonesia, cet. V, Jakarta: Balai Buku Ikhtiar, 1959

Vogel, Frank E. dan Samuel L. Hayes, Islamic Law and Finance: religion, Risk, and Return, London, Boston: Kluwer Law International, 1998.

Zahrah, al-Imam Muhammad Abu, al-Milkiyyah wa Nazariyyah al-'Aqd fi asy-Syari'ah alIslamiyyah, t.tp: Dar al-Fikr al-'Araby, t.t.. 
Diskursus Konsep dan Prinsip Akad dalam Hukum Islam

Zarqa', Musthafa Ahmad Az-, Al-Madkhal al-Figh al-'Am, juz II, Beirut: Dar al-Fikr, t.t.

Zuhaily, Wahbah az-, Al-Figh al-Islami wa Adillatubu, cet. III, jilid IV, Damsyiq: Dar al-Fikr, 1996. 